\title{
Discussing options between patients and health care professionals in genetic diagnosis: ethical and legal criteria
}

\author{
Pilar Nicolás \\ University of Deusto, University of the Basque Country, Universidad de Deusto, Avenida de las Universidades, Bilbao, Spain
}

Key words: genetic data, genetic testing, patients' rights, privacy, confidentiality, biological samples, DNA, law

Corresponding author: Pilar Nicolás, Interuniversity Chair in Law and the Human Genome, University of Deusto, University of the Basque Country, Universidad de Deusto, Avenida de las Universidades, 24, Postal Code: 48007, Bilba0, Spain,e-mail:pnicolas@genomelaw.deusto.es

Submitted: 16 May 2007

Accepted: 30 August 2007

\begin{abstract}
The specific characteristics of genetic data lead to ethical-legal conflicts in the framework of genetic diagnosis. Several international organisations, including UNESCO and the Council of Europe, have enacted rules referring to the use of genetic information. This paper discusses possible legal and ethical criteria that could be used in genetic testing.
\end{abstract}

\section{Introduction}

Specific questions regarding the ethics of genetic testing in cancer diagnosis have been raised because of the specific characteristics of the data obtained. The obtaining and use of genetic data have several peculiar implications for the rights of the patients and their relatives, and frequently practitioners and researchers face new conflicts, to which law and ethics try to give an answer. This concern has increased because, in general, law cannot provide a concrete answer to each concrete situation and, furthermore, there is no regulation of genetic analysis or genetic data in several countries. For these reasons, practitioners often need to make personal decisions in these situations. Some criteria to manage genetic information in cancer diagnosis will be presented in this article.

\section{The specific characteristics of genetic data}

It has been proposed that if genetic data are different from other health data they require specific ethical and legal reflection. This position is known as genetic exceptionalism [1].

As has been said, some characteristics of genetic data are shared by other health data, but what is peculiar is the presence of all of these special characteristics and this circumstance means that around the genetic data several different interests are involved, and this has real effects, such as the need for recommendations in this field.

In 2004, the European Commission published a document with twenty-five recommendations on ethical, legal and social implications of genetic testing in which it said that "genetic exceptionalism should be avoided, internationally, in the context of the EU and at the level of its Member States. However, the public perception that genetic testing is different needs to be acknowledged and addressed. All medical data, including genetic data, must satisfy equally high standards of quality and confidentiality" [2]. It is true that the principles to be applied to solve the conflicts dealing with the treatment of genetic data are also 
applicable to conflicts in the field of health information in general and in this sense the ethical and juridical basis of the protection is the same. However, those conflicts are different and therefore a particular projection of the general principles to the problems raised in genetic testing is needed. The fact that the European Commission felt the need to publish its twenty-five recommendations also suggests the exceptional nature of genetic data.

The International Convention on Law and Biomedicine pays attention to the human genome in a particular chapter, and to predictive genetic testing in article 12, stating: "Tests which are predictive of genetic diseases or which serve either to identify the subject as a carrier of a gene responsible for a disease or to detect a genetic predisposition or susceptibility to a disease may be performed only for health purposes or for scientific research linked to health purposes, and subject to appropriate genetic counselling" [3].

Moreover, on 16 October 2003, the UNESCO enacted the International Declaration on Human genetic data [4], which points out that human genetic data have special status because:

(1) they can be predictive of genetic predispositions concerning individuals;

(2) they may have a significant impact on the family, including offspring, extending over generations, and in some instances on the whole group to which the person concerned belongs;

(3) they may contain information the significance of which is not necessarily known at the time of collection of the biological samples;

(4) they may have cultural significance for persons or groups.

It could be added that [5]:

(5) genetic data remain the same throughout life (and after death);

(6) they can be obtained from all cells of the human body (so the parts separated from the body are a support of the information);

(7) they can be found unexpectedly;

(8) there is great scientific interest in the study of individuals' genomes.

The principles of the UNESCO Declaration are applied to the genetic data, as well as to the proteomic data and to the biological samples. That is to say, the Declaration chooses a wide frame of application, which is suitable to achieve adequate protection of the rights of the subject. Let us remember that biological samples are a physical support of all the genetic information of an individual and this material is not under the protection of data protection laws. Because of the rapid accumulation of biological samples in hospitals and research centres and of the scientific interest in use of these samples, the protection that is granted to the genetic information must be extended to the biological sample as a physical support of information.

Secondly, another question that has been debated in different forums is the concept of genetic information regarding its specific protection. In this matter, there are two options: the first one is to restrict the concept to the information obtained from the analysis of nucleic acids; and the second one is wider, and includes any genetic information obtained from any scientific analysis or (routine) genetic counselling.

The Declaration has chosen this second notion correctly. The alternative would be to establish two separate categories of information. However, these two types of information can both lead to (very similar) genetic diagnoses. For example, DNA testing as well as taking and verifying a family history and performing physical examinations looking for external signs of hereditary syndromes could each lead to a genetic diagnosis.

\section{The projection of the rights of patients in genetic diagnosis}

Conflicts in genetic counselling practice are in fact legal conflicts between rights or interests of persons involved somehow in the genetic diagnosis. The more objective way to solve these conflicts is an approach to the legal framework in this field. It is true that in some countries there is no legal regulation on genetic analysis [6], but general legal principles can be projected to this specific field, and there are some international legal instruments, as discussed previously, with juridical or ethical value in these countries.

\section{Privacy and confidentiality}

One of the most frequent dilemmas in the process of genetic counselling is how to manage genetic information relevant for the index case in a family, when he/she does not want to share it with relatives [7], that is to say, how to solve a conflict between the right to privacy (of the index case) and the right to health protection (of the family).

Some believe that the subject of the genetic information is not the individual but the biological family, and that therefore the duty of secrecy of genetic information does not apply in relation to the biological family of the patient [8].

According to this position, the biological family is the juridical subject of the genetic information, because the genetic characteristics are shared between its 
members. Following this, the traditional model of privacy in the health care system that is based on the extreme individualism of western cultures has to be changed [9].

The nondirective genetic council is the one where the physician does not interfere in the individual decisions of the patient, and provides the freedom to take individual decisions. According to the aforementioned position, the nondirective genetic council is neither ethical nor effective. This is because the family is not just a biological reality or a set of separate individuals. On the contrary, the "genetic family" has to be taken into account in the legal framework. The decisions to be taken in relation to the genetic information correspond to more than one individual. In conclusion, in relation to the genetic information there has arisen a new legally relevant group, the biological group. All its members have a right of access to the genetic information of the other members. From this legal point of view, genetic information on one relative from a family would belong to all relatives.

However, we have to bear in mind that, at least from the biological perspective, it is not defensible to view the total identification of the members of the family as one and the same subject. This is because the extent of genetic material shared between relatives is a probability that depends on the inheritance mechanisms. For this simple reason, genetic information on a particular individual does not have equal implications for each of the other relatives. We also have to bear in mind that it is difficult to delimit the extent of the group that has to be considered the subject of the genetic information (cousins, second cousins, third cousins, etc.?). In addition, the gene expression also depends on other non-genetic factors (cultural, environmental, habits etc.). These are different between individuals, even between monozygotic twins. Therefore, carrying the same mutation does not imply the same consequence for two individuals.

Moreover, as far as we know, the national legislations have not adopted specific criteria that consider as subject of the genetic information individuals other than the one from whom it is obtained. This criterion is also followed in international regulations mentioned before, such as the Universal Declaration of UNESCO on the protection of genetic data, or the Convention of Biomedicine of the Council of Europe, which recognize the rights regulated for an individual.

So, and according to the UNESCO Declaration, human genetic data should not be disclosed or made accessible to third parties, in particular employers, insurance companies, educational institutions and the family, except in two cases:

a) for an important reason of public interest in cases restrictively provided for by domestic law consistent with the international law of human rights, or b) when the prior, free, informed and express consent of the person concerned has been obtained provided that such consent is in accordance with domestic law and the international law of human rights.

That is to say that the general rule or principle is the duty of confidentially and only if a law authorises or the patient consents could the physician reveal this information to others. However, as stated before, conflicts can exist between this duty and the possibility to prevent harm in relatives by informing them of the genetic diagnosis in their family [10]. The most appropriate action in these cases is to try to convince patients to inform their relatives, and the best option is to discuss this with patients at the beginning of the process of genetic counselling.

Still, the breach of the duty of professional secrecy can be justified in some circumstances [11], such as the need to protect other rights or the obligation to carry out other duties.

In the healthcare framework, physicians usually confront various conflicts between the duty of secrecy and the need to avoid important harms. These conflicts arise, for example, in relation to contagious diseases (such as AIDS) or diseases of another nature (such as psychiatric disorders).

A similar conflict can arise in relation to information on a hereditary disorder given the possibility that other members of the family may carry the gene for this disorder. But what harm would be avoided in this case by the breach of the duty of secrecy? To answer this question the seriousness of the disease, the existence of therapy or preventive measures, and the possibility that the relatives might know by other means the contingency of carrying the pathological gene, must be taken into account [12]. Likewise, it must be taken into account whether these relatives would wish not to know such a circumstance.

Spouses and partners could also have an interest in knowing the possibility of their offspring being born with a genetic predisposition to cancer. This situation is different from the one that involves the blood relatives since the negative effects of the secret could be more evident. It is true that spouses and partners have a general duty to take care of the offspring, but it would be difficult (not impossible) to find a direct and adequate relation between the harm (the impossibility of taking care of the offspring) and the omission of genetic information. Furthermore, the omission of the information could be justified in the exercise of the right to privacy. There is no general rule in this sense; the conflicts should be resolved case by case.

Another interesting point related to access to family data is the question of protection of the clinical records 
of the deceased patients, which in the context of genetic counselling could be very useful. Directive 95/46/EC [13] on the protection of individuals with regard to the processing of personal data does not mention the protection of the data of the deceased (because personal rights cease after death), but from the ethical perspective the duty to secrecy remains even in this case. Rules regarding access to the clinical records of the deceased families have to respect the same principles applied to solve conflicts between family members taking into account the rule of proportionality of the damage [14]. In the case of use of biological samples, these materials should not be removed or supplied for research activities if the deceased person is known to have objected to it (article 13 of Recommendation $\mathrm{R}$ (06) 4 of the Council of Europe, on research on biological materials of human origin [15]).

In addition, the issue of informing relatives of their risk is now being cast in terms of familial and social responsibility [10]. Moreover, it has been discussed whether not communicating a genetic diagnosis with relatives could be the basis for legal responsibility because of a breach of duty. This conflict has been analysed even in courts, for example in two interesting court decisions from the United States that have been commented on by Gary McAbee, Hack Sherman and Barbara Davidoff-Feldman [16]. We do not know any juridical rules in this sense, so general rules about legal responsibility should be followed to evaluate the consequences of the omission. In brief, firstly, a criminal responsibility derived of an omission of help will arise if an imminent and obvious risk could have been avoided with the disclosure of the information. It seems that only in very exceptional cases are these circumstances found in the omission of genetic information. Secondly, a civil responsibility would arise. In this sense it is important to identify the duty that has been breached, as could be the duty of care (only for the physician's patients). The American Society of Clinical Oncology believes that the cancer care provider's obligations (if any) to at-risk relatives are best fulfilled by the communication of familial risk to the person undergoing testing, emphasizing the importance of sharing this information with family members so that they may also benefit [17].

Regarding the responsibility of the patient who does not communicate the genetic data to his/her relatives, as there is no specific regulation it has to follow the general rule. Hence, in this case, it is important to identify a duty breached, for example the duty to take care of offspring. Very interesting in this sense is the exception to this general rule in the French Law $n^{\circ}$ 2004-800 du 6 août 2004 relative à la bioéthique, according to which, the fact that the patient does not disclose to his or her family information related to a genetic anomaly cannot be the basis for liability against him or her («Le fait pour le patient de ne pas transmettre l'information relative à son anomalie génétique dans les conditions prévues au troisième alinéa ne peut servir de fondement à une action en responsabilité à son encontre»).

\section{The right to decide whether to learn the tests results}

The Biomedicine Convention of the Council of Europe mentioned explicitly recognition of the right "not to know" in the biomedical field. The coming into force of this Convention has represented for some countries an innovation in this respect. This is because it incorporates into the national law a new right or a new dimension of the right to self determination.

According to article 10: "1. Everyone has the right to respect for private life in relation to information about his or her health. 2. Everyone is entitled to know any information collected about his or her health. However, the wishes of individuals not to be so informed shall be observed. 3. In exceptional cases, restrictions may be placed by law on the exercise of the rights contained in paragraph 2 in the interests of the patient".

The UNESCO Declaration says that when human genetic data, human proteomic data or biological samples are collected for medical and scientific research purposes, the information provided at the time of the consent should indicate that the person concerned has the right to decide whether or not to be informed of the results.

The right not to know is part of the right to the autonomy of the patient that must be respected, even if its exercise could imply damage or risk to his or her health. So the same can be said about the right not to be informed.

The exercise of this right is not an obstacle to the validity of informed consent. For example, a patient can consent to a removal of a tumour without knowing the characteristics of it. This is the rule stated in the Biomedicine Convention of the Council of Europe.

But there could be exceptions to this principle that have to be regulated by each national law. It is not clear whether the interest of the patient could be one of these exceptions.

When appropriate, the right not to be informed should be extended to identified relatives who may be affected by the results. However, it must be taken into account that, in many situations, the wish of the subject is not certainly known. That is the case when unexpected information is found or when the relatives do not know anything about the possibility of carrying a disease. 
In each particular situation, concrete benefits and adverse consequences of the communication must be taken into account when deciding about informing. According to the guide to clinical practices in relation to familial aspects of cancer [18] for those found to carry a mutation, potential benefits include:

- they can be informed about the chances that their children have of carrying the mutation; consequently they can contribute to advice to their children to be tested;

- they can make informed decisions about initiating a pregnancy, fetal testing and possible termination of pregnancy;

- they can be advised on surveillance aimed at early diagnosis, and on preventive treatment.

For those found to carry a mutation, potential adverse consequences include:

- anxiety based on concern for themselves and their own future;

- anxiety and guilt regarding the now high-risk status of their children;

- difficulties to be confronted with regard to choices about future pregnancies;

- the stress of being the bearer of bad news in the family;

- disruption to family relationships;

- concerns about uncertain consequences of the recording of the test result;

- uncertainty about the possible misuse of the information, at the present time or in the future.

These factors must be applied to the particular situation, and regarding the result of evaluation of all of them, a presumption of the wish of being informed must be established.

The presumptions have to be established bearing in mind the benefit and the prejudice to the subject. Therefore, except in some clear situations, the physician will face important doubts in taking a decision whether or not to inform the patient about any unexpected findings. In this decision not only objective factors must be taken into account, such as the possibility of therapy, but also subjective ones, such as the personality of the patient, the consequences of getting this information, and other familiar circumstances.

Recommendation R (92) 3 of the Council of Europe, on genetic testing and screening for health care purposes [19], establishes that "In conformity with national legislation, unexpected findings may be communicated to the person tested only if they are of direct clinical importance to the person or the family. Communication of unexpected findings to family members of the person tested should only be authorised by national law if the person tested refuses expressly to inform them even though their lives are in danger" (Principle 11).

This position has been developed by Principle 8.4 of Recommendation R (97) 5 of the Council of Europe on Protection of Medical data [20]. According to this Principle, the person subjected to genetic analysis must be informed of unexpected findings if the domestic law does not prohibit the giving of such information; or the person himself has asked for this information; or the information is not likely to cause serious harm to his/her health, or to his/her consanguine or uterine kin, to a member of his/her social family, or to a person who has a direct link with his/her genetic line, unless domestic law provides other appropriate safeguards. The person should also be informed if this information is of direct importance to him/her for treatment or prevention.

So, the Recommendation restricts the circumstances in which the unexpected findings should not be communicated. In conclusion, the doubtful cases that remain at the moment of deciding on whether to report of an unexpected finding are very limited. The cases are those in which this information does not have repercussions for the health of the individual involved because the mutation found does not have great clinical significance or there is no therapy or prevention known, or it will not be transmitted to the offspring. In these cases, according to Recommendation (97) 5 it is not necessary to inform.

When consent is requested for using samples with scientific research purposes, the most appropriate behaviour is to ask the wish of the subject regarding the communication of unexpected findings. Recommendation R (97) 5 of the Council of Europe on the Protection of medical data states that "Before a genetic analysis is carried out, the data subject should be informed about the objectives of the analysis and the possibility of unexpected findings" (principle 5.4).

\section{Non-discrimination}

The Explanatory Report of the Biomedicine Convention [21] recognizes that the mapping out of the human genome, which is advancing rapidly, as well as the development of the genetic tests linked to it, are likely to bring substantial advances in the prevention of illnesses and the administration of treatment. But genetic testing also raises considerable concerns. Among these the most widespread is probably the concern that genetic testing may become a means of selection and discrimination. 
The fundamental principle established in Article 11 of the Biomedicine Convention is that any form of discrimination against an individual on grounds of his or her genetic heritage is prohibited, as has been mentioned, but it cannot prohibit positive measures which may be implemented with the aim of reestablishing a certain balance in favour of those at a disadvantage because of their genetic inheritance.

According to the UNESCO Declaration it must be ensured that human genetic data and human proteomic data are not used for purposes that discriminate against an individual or for purposes that lead to the stigmatization of an individual, a family, a group or communities.

In this regard, appropriate attention should be paid to the findings of population-based genetic studies and behavioural genetic studies as well as to their interpretations.

Human genetic data and human proteomic data may be collected, processed, used and stored only for the following purposes:

(1) diagnosis and health care, including screening and predictive testing;

(2) medical and other scientific research, including epidemiological, especially population-based genetic studies, as well as anthropological or archaeological studies;

(3) forensic medicine and civil, criminal and other legal proceedings;

(4) any other purpose consistent with the Universal Declaration on the Human Genome and Human Rights and the international law of human rights.

It has been said that before a patient decides to undergo genetic testing, he or she should be acquainted through genetic counselling with the possible implications for themselves and their blood relatives for insurance and employment of having the test. In clinical genetic practice this is referred to as the informed consent procedure. But taking into account the general prohibition of discrimination enacted in almost all the national legal frameworks and in the mentioned Convention on Biomedicine of the Council of Europe, this precaution could suggest an unnecessary wrong perception to the patient and to society.

To ensure non-discrimination practices, there has been recommended a statement of a specific regulation at the European level that develops the provision of the Bioethics Convention according to which, as said, any form of discrimination against a person on grounds of his or her genetic heritage is prohibited [22].

\section{Patient's rights and biological samples}

Scientific interest in the use of biological samples as a research tool has increased simultaneously with the increase in the knowledge of human genetics. In a rapidly evolving field such as cancer genetics, it is inevitable that research and clinical work will be closely entwined [23]. Researchers usually ask for the samples stored with diagnostic purposes for their use in research [24].

In many countries, a legislative provision that harmonizes the needs of the advances of science with suitable protection of the rights of the subjects affected does not exist. A regulation of the obtaining and utilization of biological samples in scientific research is needed. Some national and international institutions have enacted several guidelines in this field, and in general in the creation of biobanks [25].

We must highlight that UNESCO's Declaration on human genetic data applies, as stated in the first article, to "human genetic data, human proteomic data and to the biological samples from which they are derived"; nevertheless, in my opinion, the expression "which they are derived" is not accurate as it leads one to think that the text applies only to samples that have already been analysed, and actually, through the text, the samples are protected also before this process.

We must also mention some documents of the Council of Europe, for example Recommendation $R$ (92) 3 on genetic testing and screening for health care purposes [26], which indicates in principle 8 that the samples and the tissues of the body are supports of information that must be protected in the same way as processed personal data, and the most important one: Recommendation $\mathrm{R}(06) 4$ on research on biological materials of human origin [27].

The Biomedicine Convention does not address this particular question, but it contains some rules that must be taken into account. The Additional Protocol to this Convention, concerning biomedical research of 25 January, 2005, states that before being asked to consent to participate in a research project, the persons concerned shall be specifically informed, according to the nature and purpose of the research, among other things, of any foreseen potential further uses, including commercial uses, of the research results, data or biological materials (principle 13) [28]. In addition, the Steering Committee on Bioethics published a proposal for a Protocol to this Convention on the use of archived human biological materials in biomedical research (17 October, 2002).

There does not exist a European community norm (such as a Directive) regulating the use of human biological samples in scientific research. Therefore, it is necessary to attend to other principles in order to solve the conflicts that arise in these situations. 
Directive 2004/23/EC on setting standards of quality and safety for the donation, procurement, testing, processing, preservation, storage and distribution of human tissues and cells [29] lays down standards of quality and safety for human tissues and cells intended only for human applications as is stated in its article one. This Directive does not apply to in vitro research: as is stated in article 2: "This Directive shall apply to the donation, procurement, testing, processing, preservation, storage and distribution of human tissues and cells intended for human applications and of manufactured products derived from human tissues and cells intended for human applications".

In this normative framework reviewed, a text which seems to be more specific and extensive in this field is Recommendation $\mathrm{R}(06) 4$ on research on biological materials of human origin, so the most suitable is to follow its criteria.

Depending on the original reason for obtaining the biospecimens, research or other purposes (including the practical clinical use for diagnostic or presymptomatic genetic testing), two hypotheses can be distinguished.

If the sample has been obtained for research, the aforementioned Recommendation states that "Information and consent or authorisation to obtain such materials should be as specific as possible with regard to any foreseen research uses and the choices available in that respect. An intervention should only be carried out to obtain biological materials for storage for research purposes if it complies with the Additional Protocol concerning biomedical research" (principles 10 and 11). According to this Protocol, "Research shall not involve risks and burdens to the human being disproportionate to its potential benefits. In addition, where the research does not have the potential to produce results of direct benefit to the health of the research participant, such research may only be undertaken if the research entails no more than acceptable risk and acceptable burden for the research participant (...)" (article 6).

More problematic is the case when scientific research wants to make use of "residual biological materials". In principal, the express consent to use the sample for research purposes is required at the moment of the consent to the intervention or extraction. However, this does not always happen. The question that is raised is whether the express consent of the subject is needed to use the sample in scientific research.

We must take into account that the human biological sample, from the legal point of view, should be considered from a double perspective, since it has a double nature. On the one hand, it is a part separated from the human body. On the other hand, it is a medium of information. The rights of the subject in relation to the sample vary depending on the perspective adopted.
Regarding the sample simply as a part removed of the body, it must be taking into account that the body is the "physical support of the personality", that is to say, the living human body is considered as a "person". This is opposed to the category "thing", which is consequently excluded as an object of rights. Nevertheless, the parts of the body removed from it are not included in this category, as they no longer form a part of the "physical support of the personality". As biological material removed from the body, an extracted sample is neither an element of the personality nor an object of fundamental rights. It is a thing.

As it is known, in relation to its belonging, things are patrimony (public or private) or not (because they never belonged to anybody - res nullius - or they were abandoned - res derelictae). In relation to commerce, they are things in comercio or extra comercium.

The removed parts of the body are not public domain as they belong neither to the State nor to the cities. So, they are either res nullius or res derelictae, or are of private property.

The extracted sample must be considered as the property of the individual as it is a link that joins them, from which the use of such derives the harm to the rights of that individual. This is coherent with the right to free disposition which the individual enjoys to donate parts of the body, according to which the subject can decide the destiny of his or her blood, organs and gametes.

The individual, as owner of the sample, has the power of disposition, which has to be exercised through the manifestation of her wish, in an express or presumed way.

Starting from the need of the subject's consent as a requirement of the respect of her right to autonomy, it can be considered appropriate to accept presumptions and therefore not to demand express consent.

Nevertheless, article 22 of the Biomedicine Convention seems contrary to this position. The Convention states that "When in the course of an intervention any part of a human body is removed, it may be stored and used for a purpose other than that for which it was removed, only if this is done in conformity with appropriate information and consent procedures". However, it could be interpreted that appropriate consent would be a presumed one. Furthermore, the appropriate information could refer to the fact that the subject can obtain all the information concerning the research. As a matter of fact, in the explanatory report (paragraph 137) it is stated that "The information and consent arrangements may vary according to the circumstances, thus allowing for flexibility since the express consent of an individual to the use of parts of his body is not systematically needed. Thus, sometimes, it will be impossible, or very difficult, to find the persons concerned again in order to ask for their consent. In some cases, it will be sufficient for a patient or his or her representative, 
who have been duly informed (for instance, by means of leaflets handed to the persons concerned at the hospital) not to express their opposition. In other cases, depending on the nature of the use to which the removed parts are to be put, express and specific consent will be necessary, in particular where sensitive information is collected about identifiable individuals."

Moreover, article 12 of Recommendation (06) 4, established that "Biological materials removed for purposes other than storage for research should only be made available for research activities with appropriate consent or authorization, or in accordance with the provisions of Article 22 paragraph 1.ii", and this refers to identifiable biological materials.

In fact, regarding the sample as a medium of personal information, it is important to distinguish between personal and non-personal (anonymised) information. In the first case, following the principles of protection of personal data, express consent must be required.

Taking into account the Directive on data protection, the recommendation of the Council of Europe mentioned states:

i) Identifiable biological materials are those biological materials which, alone or in combination with associated data, allow the identification of the persons concerned either directly or through the use of a code.

In the latter case, the user of the biological materials may either:

a) have access to the code: the materials are hereafter referred to as "coded materials" or

b) not have access to the code, which is under the control of a third party: the materials are hereafter referred to as "linked anonymised materials".

ii) Non-identifiable biological materials, hereafter referred to as "unlinked anonymised materials", are those biological materials which, alone or in combination with associated data, do not allow, with reasonable efforts, the identification of the persons concerned.

Unlinked anonymised biological materials may be used in research provided that such use does not violate any restrictions placed by the person concerned prior to the anonymisation of the materials.

\section{Anonymisation should be verified by an appropriate review procedure}

This criterion must be applied to research with biological samples and its storage in biobanks. If the samples are kept in a manner that establishes the possibility of associating them with a subject through reasonable means, the principles of protection of personal data must be applied. Therefore, the express consent of the subjects must be required in order to analyse them. If the link between the sample and the identity cannot be established, the sample is made anonymous and therefore the data obtained must not be considered as personal.

However, according to the Recommendation of the Council of Europe, there could be an exception to this general rule, because it is established that the biological material can be used in a research project without the consent of the person concerned when an independent evaluation certifies that:

- contacting the person concerned is not possible with reasonable efforts, and:

a) the research addresses an important scientific interest;

b) the aims of the research could not reasonably be achieved using biological materials for which consent can be obtained;

c) there is no evidence that the person concerned has expressly opposed such research use.

\section{Discussion and Conclusions}

Since the nineteen nineties there has been a concern to develop rules referring to patients' rights in genetic diagnosis. Researchers and physicians would like to have practical criteria to carry out their work with respect to the subjects' rights with juridical security.

Several texts have been enacted from national and international institutions, with juridical or ethical nature. From the international perspective, the Declaration of UNESCO on human genetic data and the Recommendation of the Council of Europe on research on biological materials of human origin are especially important. But these instruments do not have juridical force - not as a national or international law would have.

Some European countries have laws regarding the use of genetic information, but often only on very specific aspects (for example assurance), and there are several differences between these criteria.

The European Union Directive on data protection, that has been incorporated in the national legal framework of the member states, is a good reference in the use of personal data in general, but not enough regarding the use of genetic personal data. The work in the development and interpretation of the Directive that is now being carried out in the European Union could be an adequate way to unify criteria and elaborate juridical European instruments. In this process, the principles followed in other international texts mentioned have to be taken into account.

The objective should be to develop concrete rules to solve the conflicts in practice, but it has to be remembered that laws cannot refer to every particular 
case, and that it is difficult to eliminate the factor of the physician's decision.

Regarding scientific research, the Ethics Committees have an important role in the review of the projects. This control, which includes a review of the informed consent of the research subjects, ensures that the appropriate criteria are observed and gives the researcher a guarantee of good practice. In relation to the diagnosis, the principle to follow is that the genetic diagnosis should be established within the framework of genetic counselling, meaning adequate structures, protocols, professionals and multidisciplinary services, to provide global care for the patient.

\section{References}

1. Green MJ, Botkin JR. "Genetic exceptionalism" in medicine: clarifying the differences between genetic and nongenetic tests. Ann Intern Med 2003; 138: 571-575.

2. http://europa.eu.int/comm/research/conferences/2004/genetic/ pdf/recommendations_en.pdf.

3. http://conventions.coe.int/Treaty/EN/Treaties/Html/164.htm.

4. http://portal.unesco.org/shs/en/ev.php-URL_ID = 1882\&URL_DO= DO TOPIC\&URL SECTION=201.html.

5. Di Pietro ML, Giuli A, Spagnolo AG. Ethical implications of predictive DNA testing for hereditary breast cancer. Ann Oncol 2004;15 (Suppl. 1): 165-170.

6. http://ec.europa.eu/research/biosociety/pdf/bioethics-surveytest2106.pdf.

7. Harris M, Winship I, Spriggs M. Controversies and ethical issues in cancer-genetic clinics. Lacet Oncol 2005; 6: 301-310.

8. Knoppers BM. Towards a reconstruction of the "genetic family": new principles? Int Dig Health Legis 1998; 49: 241-253.

Berg K. Le respect de la vie privée par opposition à la communication des informations. Ethique et génétique humaine. Actes du 2e Symposium du Conseil de l'Europe sur la bioéthique. 1994; 135.

Parker M, Lucassen AM. Genetic information: a joint account? BMJ 2004; 329: 165-167.

9. Kegley JA. Using genetic information: the individual and the community. Med Law 1996; 15: 377-389.

10. Koch L, Svendsen MN. Providing solutions - defining problems: the imperative of disease prevention in genetic counselling. Social Science \& Medicine 2005; 60: 823-832.

11. Royal College of Physicians and The British Society for Human Genetics The rule of confidentiality in genetics counselling is no absolute. Consent and confidentiality in genetic practice. Guidance on genetic testing and sharing genetic information. A report of the Joint Committee on Medical Genetics 2006.

12. Hansson M. Ethical management of hereditary cancer information. Acta Oncol 1999; 38: 305-308.

13. http://eur-lex.europa.eu/LexUriServ/LexUriServ.do? uri=CELEX: 31995L0046:EN:HTML.

14. Royal College of Physicians, The British Society for Human Genetics. Consent and Confidentiality in Genetic Practice. A report of the Join Committee on Medical Genetics 2006; 12-13.

15. http://wcd.coe.int/NiewDoc.jsp?id=977859\&BackColorlnternet= 9999CC\&BackColorlntranet=FFBB55\&BackColorLogged $=$ FFAC75.

16. Mcabee G, Sherman H, Davidoff-Feldman B. Physician's duty to warn third parties about the risk of genetic diseases. Downloaded from http://pediatrics.aappublications.org/cgi/reprint/102/1/140.
17. American Society of Clinical Oncology Policy Statement Update: genetic testing for cancer susceptibility. Downloaded from http://jco.ascopubs.org/cgi/reprint/21/12/2397.

18. National Health and Medical Research Council, Australia, 1999. http://www.nhmrc.gov.au/publications/synopses/ files/cp67.pdf.

19. https://wcd.coe.int/com.instranet.InstraServlet? Command=com. instranet.CmdBlobGet\&Docld $=601490 \&$ SecMode $=1 \&$ Admin $=$ $0 \&$ Usage $=4 \&$ Instranetlmage $=43355$.

20. https://wcd.coe.int/com.instranet.InstraServlet? Command= com .instranet. CmdBlobGet\&Docld $=560580 \&$ SecMode $=$ $1 \&$ Admin $=0 \&$ Usage $=4 \&$ Instranetlmage $=43009$.

21. http://www.bioethics.nih.gov/international/declarat/convexpl.htm.

22. http://ec.europa.eu/research/biosociety/pdf/genetic_testing_ eur20446.pdf\#search=\%22herman\%20nys\%20genetic $\% 20$ tests\%20discrimination\%22.

23. Richards MP. Genetic Counselling for those with a family history of breast or ovarian cancer - current practice and ethical issues. Acta Oncol 1999; 38: 559-565.

24. National Bioethics Advisory Commission, Research involving human biological materials: ethical issues and policyt guidance, vol. I (Report and Recommendations), Maryland, 2000, pp. 1 - 16; http://bioethics.georgetown.edu/nbac/hbm.pdf. Furness P. Consent to using human tissue. BMJ 2003; 327: 759-760.

25. Australia Law Reform Commission. Essentially Yours: The Protection of Human Genetic Information in Australia. 2003. Comité Consultatif National D'ethique. Problémes éthiques posés par les collections de matériel biologique et les donnés d'information associeés: biobanques, biothéques. 2003: 77; http://www.ccne-ethique.fr/francais/avis/a_077.htm.

Council of Europe, Steering Committee on Bioethics (CDBI). Proposal for an instrument on the use of archived human biological materials in biomedical research. 2002.

The European Group on Ethics in Science and New Technologies to the European Commission. Ethical aspects of human tissue banking. 1998.

European Society of Human Genetics, Data storage and DNA banking for biomedical research: technical, social and ethical issues. Recommendations of the European Society of Human Genetics. 2003.

National Bioethics Advisory Commission. Research involving human biological materials: ethical issues and policy guidance. 2000: 1, 2.

Nationaler Ethikrat. Opinion: Biobanks for research. 2004; http://www.ethikrat.org/_english/publications/Opinion_Biobanks -for-research.pdf.

Nuffield Council on Bioethics. Human tissue and biological samples for use in research. 1995.

Medical Research Council. Human tissue and biological samples for use in research. 2001 ; http://www.mrc.ac.uk/Utilities/ Documentrecord/ index.htm? $\mathrm{d}=$ MRC002420.

Research based on archived information and samples. Royal College of Physicians Committee on Ethical Issues in Medicine. JR Coll Physicians Lond 1999; 33: 264-266.

Organisation for Economic Co-operation and Development. Biological resource centres. 2001. Review of the current status, activities and future of existing biological resource centres, 2001; http://www.oecd.org/dataoecd/49/40/1912000.pdf.

26. http://www.coe.int/T/E/Social_Cohesion/Health/ Recommendations/Rec(1992)03.asp.

27. https://wcd.coe.int/NiewDoc.jsp? id =977859\&BackColorlnternet= 9999CC\&BackColorlntranet=FFBB55\&BackColorLogged $=F F A C 75$.

28. http://conventions.coe.int/treaty/en/Treaties/Html/195.html.

29. http://eur-lex.europa.eu/smartapi/cgi/sga_doc? smartapi!celexapi! prod!CELEXnumdoc\&lg $=$ en $\&$ numdoc $=32004 \mathrm{LO023} \&$ model $=$ guichett. 